\title{
LEAD ISOTOPE RATIOS IN SPANISH COALS OF DIFFERENT CHARACTERISTICS AND ORIGIN
}

\author{
M. Díaz-Somoano a, I. Suárez-Ruiz ${ }^{\text {, J.I.G. Alonso }}$, J. Ruiz Encinar ${ }^{\text {, }}$, \\ M.A. López-Antón ${ }^{\mathrm{a}}$ and M.R. Martínez-Tarazona ${ }^{\mathrm{a}, *}$ \\ ${ }^{a}$ Instituto Nacional del Carbón (CSIC), Francisco Pintado Fe, $n^{\circ}$ 26, 33011 Oviedo, \\ Spain. \\ ${ }^{b}$ Departamento de Química Física y Analítica, Universidad de Oviedo, Julián Clavería \\ 8, 33006 Oviedo, Spain
}

* Corresponding author: Telephone: +34 985118988, Fax: +34 985297662

E-mail: rmtarazona@incar.csic.es (M.R. Martínez-Tarazona) 


\begin{abstract}
Lead isotope ratios in coals of different rank from several Spanish basins were estimated and related with their characteristics. The isotope ${ }^{206} \mathrm{~Pb} /{ }^{207} \mathrm{~Pb}$ ratio values of the coals studied range between 1.13-1.21, with the exception of some coal samples from the Cretaceous which are more radiogenic. Coals were classified into groups according to their lead isotope ratios. These in turn were related to the isotope ratios of the minerals galena, pyrite, chalcopyrite, and carbonates. Some of the low-rank coals, in which lead might be expected to be associated to the organic matter, were not found to be related with isotope ratios of minerals. The isotope ratios of the individual densimetric fractions separated from a bituminous coal are different to those of the raw coal. The differences between these isotope ratios may not only be due to the diverse origin of lead in different coals, but also to the possible presence of several lead species incorporated from various sources in a particular coal. The results of this work represent an important contribution to the lead isotope ratio database essential for the accurate interpretation of data regarding pollution sources.
\end{abstract}

Keywords: lead, isotope ratio, minerals in coal, trace elements in coal 


\section{Introduction}

Lead is a trace element in coals and is generally present in concentrations ranging between $2.0-80 \mathrm{ppm}$. Although the mode of occurrence of this element may differ from coal to coal, it is mainly thought to occur in galena $(\mathrm{PbS})$, clausthalite ( $\mathrm{PbSe})$, and associated with some Ba minerals or with pyrite and other sulfides. Lead may also be organically bound to organic matter in low rank coals (Swaine, 1990). The origin of trace elements in coal can be traced to the history of the coal swamp, geological changes and atmospheric inputs. Interactions between geological, physicochemical and biochemical factors are important determinants of the concentration and distribution of trace elements in coal seams (Swaine, 1990). As a consequence, trace elements in coal may have diverse origins. Knowledge of the mode of occurrence of a hazardous element, such as lead, is of great interest because it may help us to understand its behaviour during coal conversion processes and its potentially hazardous activity. Moreover, interest in lead is enhanced by the fact that by comparing its isotope ratios in ores, contaminant sources and contaminated sites, it can be used as a tracer.

Natural lead is normally composed of four stable isotopes with masses of 204, 206, 207 and 208, and with abundances of 1.4, 24.1, 22.1 and $52.4 \%$, respectively. Only ${ }^{204} \mathrm{~Pb}$ is non-radiogenic. The other three are the end products of the radioactive decay of uranium and thorium. ${ }^{206} \mathrm{~Pb}$ is derived from the decay of ${ }^{238} \mathrm{U},{ }^{207} \mathrm{~Pb}$ from ${ }^{235} \mathrm{U}$ and ${ }^{208} \mathrm{~Pb}$ from ${ }^{232} \mathrm{Th}$. The amount of each lead isotope present in a particular ore is determined when it is formed. The isotopic ratios of lead measured in any given geological situation will depend on two major factors: i) the $\mathrm{U} / \mathrm{Pb}$ and $\mathrm{Th} / \mathrm{Pb}$ ratios in the geological context under consideration; and, ii) the amount of time during which the $\mathrm{U}, \mathrm{Th}$, and $\mathrm{Pb}$ have been associated with one another. 
Lead isotope ratios have been used for over 30 years by isotope geologists as a method of age dating and as a geological tracer (Marcoux and Milesi, 1993; Billstrom and Weihed., 1996). For a number of years, they were also employed to determine the provenance of archaeological artefacts. Nowadays lead isotope ratios are widely used to trace pollution, for which it is necessary to know the isotope ratios of a possible emission source (Renberg et al., 2002; Flament et al., 2002; Martinez Cortizas et al., 2002, Chen et al., 2005, Kylander et al., 2005). Data on lead isotope ratios for different ores and pollution sources, including some coals, are already available in the literature (Sugden et al., 1993; Walraven et al., 1997; Farmer et al., 1999; Weiss et al., 1999 and 2002; Mukai et al., 2001; Chen et al., 2005). However, most of these data were obtained for a small number of coals and there is still a need for a wide-ranging database on lead isotope ratios in coals of different origin. In this work, isotope ratios in Spanish coals of different characteristics and origin were determined for use as tracers to identify sources of pollution, to acquire useful information related to coal origin and properties, and to obtain additional data for an already well documented database on lead isotope ratios in coals.

\section{Geological setting}

\subsection{The Central Asturian Coal Basin (Carboniferous)}

This is a basin of Pennsylvanian age located in Northwestern Spain. The coal bearing succession is divided into the lower group (Lena Group) made up of limestone and sporadic, thin coal seams (Sáenz de Santa María et al., 1985; Agueda et al., 1991; Fernandez, 1995) and the upper group (Sama Group) with sandstones, commercially exploitable coal beds and occasional limestones (Fernandez, 1995). The lithological succession of this basin was formed in transitional and continental paleosedimentary 
environments in a foreland basin (Saenz de Santa Maria Benedet et al., 1985; Agueda et al.,1991; Fuente-Alonso and Saenz de Santa Maria Benedet, 1999). The Hercynian Orogeny affected all the sedimentary series (Fuente-Alonso and Saenz de Santa Maria Benedet, 1999) and towards the south of this basin an incipient metamorphism has been reported (Aller and Brime, 1985). The sedimentary environment of the coals was a swamp located on a delta plain with a relatively high water table and a humid climate. The coal rank ranges from high volatile bituminous coal to semi-anthracite and anthracite (Piedad-Sánchez et al. 2004, 2005). The samples studied in this work are from the Sama Group.

\subsection{The Peñarroya Basin (Carboniferous).}

The Peñarroya-Belmez-Espiel Coalfield (South Spain) is a narrow intramontane basin, known as the Peñarroya Basin of Pennsylvanian (Westphalian) age infilled with terrestrial sediments of lacustrine and fluvial facies and interbedded with several coal bearing units (Marques, 2002). In the Peñarroya basin there are two main chronologically successive depocentres containing specific stratigraphic successions. The general distribution of the sedimentary facies (Wagner, 1999) is similar in both cases with alluvial fan deposits passing laterally into fluvial sediments, grading into an alluvial plain and lacustrine sediments as a result of the subsidence processes in one of the margins of the Peñarroya Basin. This basin represents a sedimentary paleoenvironment of marginal lacustrine type in which fluvial transitions and several coal-bearing units are also present. The coals vary widely in rank, from high volatile bituminous coals to anthracite rank (Marques, 1993, 2002). Natural cokes are also present. 


\subsection{The Puertollano Coal Basin (Carboniferous)}

This basin (Central Spain) is of Pennsylvanian (Stephanian) age. Its sedimentary succession begins with alluvial-fan breccias on the eroded Ordovician sedimentary substratum. After the initial deposition, widespread organic strata developed into a lacustrine setting including the formation of the three major oil-shale beds and coal seams in an upward succession. The Puertollano coal seams were generated in successive stages of a lacustrine system (Wallis, 1983) probably located near a transitional environment and sporadically influenced by marine waters (Soler-Gijón, 1991; Alastuey et al., 2001). The carbonaceous series were formed in a paleomire system in the marginal zones of a lake with a potential marginal marine influence. The coals are of a high volatile bituminous coal rank.

\subsection{The Asturian Jurassic Basin.}

The most complete succession of the Asturian Jurassic (North Spain) is made up (Valenzuela et al., 1986) of two big megasequences separated by an unconformity in the Dogger-Malm transition. The lower sequence (Hettangian-Lower Bajocian) is formed by carbonated deposits cumulated in microtidal plains and in restricted lagoons later evolved to marine plains. The upper sequence is mainly detrital in its lower part, its being of Kimmeridgian age (Suarez Vega, 1974; Schudak, 1987). The terrigenous facies are specific to alluvial fans that laterally evolved to fluvial deposits. After a transgress episode, a restricted plain or lagoon developed and a small deltaic system in a predominant fluvial system was formed. Thin coal remains of lenticular shape interbedded with sandstones are located in this part of the sequence. The sample selected for this work was taken from one of these coal levels. 


\subsection{The Saldes (Pedraforca Coals) Coalfield (Upper Cretaceous)}

The geological data relating to this coalfield are also very scarce. The Saldes coalfield is located in the northeast of Spain and belongs to the Mesozoic Sub-zone (IGME, (1985). The coal seams (IGME, 1979) are located in the Berga-Tuixent Basin, an area strongly affected by the Alpine Orogeny. The productive coal series of the Saldes coalfield started with marine deposits and were then overlapped by the continental (lacustrine) sediments of the Garumnian facies in which coal seams (Pedraforca coals) developed. This Formation (Garumnian age) is chronologically located in the transition between the Upper Cretaceous and the Lower Tertiary. The coal seams are interbedded with limestones and they are of bituminous rank.

\subsection{The Utrillas-Escucha (Teruel Basin) Coalfield (Cretaceous)}

The Utrillas-Escucha coalfield is located in Northeastern Spain. Its stratigraphic succession is from the Triassic up to the Cretaceous periods. The latter period is characterized by a strong subsidence of the basin and by the development of coal seams in the so-called Escucha Formation. The sedimentary series of the Utrillas-Escucha coalfield started with marine facies (Triassic and Jurassic). The Cretaceous sedimentation is represented by the Weald and the Urgonian facies (Aptian age). By the end of the Gargarian period a regressive marine episode occurred and the detrital sediments of the Escucha Formation were deposited in sedimentary environments of a transitional type. Pardo (1979) and Querol (1990) showed that this unit was generated in a delta-estuary. Querol (1990) and Querol et al. (1991) differentiated two sedimentary environments in which the coal seams developed: the swamps of the delta plain under fresh water conditions and a belt of marshes under the influence of brackish waters. The Escucha formation is overlaid by the fluvial facies of the Utrillas Formation (upper 
Albian), and later by transgress marine facies of the Upper Cretaceous. Coals from the Escucha Formation are of subbituminous coal rank. They show high ash yield and high sulphur content.

\subsection{The As Pontes Coal Basin (Cenozoic)}

The As Pontes Coal Basin is a strike-slip coal basin of Oligocene-Miocene age located in the northwest of Spain. Sedimentation in the As Pontes Basin (Cabrera et al., 1995 and Huerta, 2001) was non-marine and developed under significant tectonic influence. It consists mainly of terrigenous sequences deposited in alluvial and lacustrine zones. These terrigenous facies are related laterally and vertically to lignites generated in swamp and marsh environments. The evolution and quality of the lignites (Cabrera et al., 1995; Huerta, 2001), was determined by tectonic evolution specific paleoclimatic conditions, the parent rock which influenced the detrital supply and water hydrochemistry, and syngenetic solutions in the basin.

\subsection{The Meirama Coalfield (Cenozoic)}

The Meirama (Miocene) coalfield (IGME, 1985), which is located near the As Pontes Basin, was generated in a limnic basin due to the activity of pre-existing faults at the end of the Alpine Orogeny. The tectonic activity formed grabens in which organic material accumulated, giving rise to thick coal seams. Like most of the basin infills in the Cenozoic Northwestern Spanish coal basins, they consist of terrigenous alluvial deposits (IGME, 1985), some of which contain exploitable coal seams. The coals from the Meirama Coalfield are of lignite rank. 


\section{Methodology}

\subsection{Coal samples}

The coal samples were obtained from the Spanish coal deposits mentioned above. All the coals are humic and most of them originate from workable coal seams. Eight bituminous coals and an anthracite from the Central Asturian Basin were analysed. Two bituminous coals and two anthracites were taken from the Peñarroya Coal Basin. Bituminous coals from the Puertollano Basin (4 samples), Asturian Jurassic Basin (1 sample) and Saldes Basin (3 samples) were also studied. One subbituminous coal from the Utrillas-Escuha coalfield, two lignites from the As Pontes basin and one from the Meirama Coalfield were analyzed. The samples were identified using sample codes with a 'B', an 'A', an "Sb"or an 'L' preceding a number for bituminous coals, anthracite, subbituminous coal and lignite, respectively.

\subsection{Densimetric separations}

A series of densimetric fractions was obtained from a bituminous coal for isotope ratio determination. They were designated as B (bituminous) plus $\mathrm{F}$ (fraction) plus a number which increases with the extent of the densimetric fraction. The density separations were carried out using $1 \mathrm{~kg}$ of coal sample in dense medium baths. Eleven (BF1-11) density fractions were obtained by consecutive immersion in dense medium baths of organic liquids (xylol, percloroetilene, and bromoform) and of increasing density (from 1.30 to $2.60 \mathrm{~g} \mathrm{~cm}^{-3}$ ). This procedure, which is a conventional coal washability test (the float sink test), is described in ASTM Standard D-4371-98. 


\subsection{Sample characterization}

All the raw coal samples were prepared for petrographic analysis according to the standard procedure described in UNE 32300 (1995), which is a modified version of the ISO 7404-2 (1985) standard. Maceral analysis and random vitrinite reflectance measurements of all the samples were carried out on a MPV-Combi Leitz microscope by means of reflected white light, using oil immersion objectives (50x) in accordance with ISO 7404-3 (1994a) and ISO 7404-5 (1994b) standards, respectively. Moisture, ash, and volatile matter contents were obtained according to the ISO 589 (2003), ISO 1171 (1997), and ISO 562 (1998) standards. C and total sulphur contents were determined using a LECO CHN 600 and a LECO SC 132 apparatus.

\subsection{Lead content and lead isotope ratio determination}

Coal ashes obtained at $500{ }^{\circ} \mathrm{C}$ were used to determine the total lead and isotope ratios. To obtain these ashes, the coal samples were burned for 1 hour at $300^{\circ} \mathrm{C}$ and then for 2 hours at $500^{\circ} \mathrm{C}$. For the isotope ratio determinations, $0.05 \mathrm{~g}$ of ash mixed with $2 \mathrm{ml}$ of $\mathrm{HNO}_{3}(65 \% \mathrm{~m} / \mathrm{v})$ was heated at $600 \mathrm{~W}$ for $6 \mathrm{~min}$ in a microwave oven. To determine the bulk lead content, an identical quantity of ash was totally dissolved in a two step program. In the first step $2 \mathrm{ml}$ of $\mathrm{HNO}_{3}+3 \mathrm{ml}$ of $\mathrm{HF}(48 \% \mathrm{~m} / \mathrm{v})$ was used to dissolve the sample during a period of $17 \mathrm{~min}$ at different intervals, applying a power of between 300 and $600 \mathrm{~W}$. The second step consisted in adding $5 \mathrm{ml}$ of $\mathrm{HBO}_{3}$ to the solution and heating it in the microwave oven for $6 \mathrm{~min}$ at $600 \mathrm{~W}$. A commercial microwave oven (Milestone MLS 1200) fitted with an EMS exhaust unit and teflon high-pressure digestion vessels (HPV80) were used to dissolve and extract the lead. After cooling, the resulting solutions were filtered and diluted to $50 \mathrm{ml}$. The total lead and isotope ratio determinations were carried out in a Hewlett-Packard model HP-4500 ICP-MS, 
equipped with a Babington nebuliser, a Peltier-cooled Scott spray chamber and a quartz torch. The detection system consisted of a quadrupole mass and an electron-multiplier. Thalium was used as internal standard (Ruiz Encinar et al., 2001). The desired concentration was obtained from a Merck $1000 \mathrm{mg} \mathrm{l}^{-1}$ stock standard solution stabilised in $0.5 \mathrm{M} \mathrm{HNO}_{3}$. Bidistilled nitric acid, obtained by the distillation of $65 \%$ nitric acid was used to dilute the stock solutions. An isotopic standard reference material, NIST SRM 981 (Natural Lead Isotope) was employed to check the accuracy and precision of the isotope measurements (Ruiz Encinar et al., 2001). The standard coal NIST SARM 20 was used as a reference material in lead determination. All the dilutions were prepared with water provided by a Milli-Ro connected to a Milli-Q system (Millipore) and Nitric acid.

\section{Results}

\subsection{Coal characterization. Petrography}

Table 1 shows the values obtained for the physical and chemical parameters, the bulk lead content and lead isotope ratios. The coals from the Central Asturian Coal Basin are bituminous and vitrinite rich with low sulfur contents (Piedad-Sánchez et al., 2004, 2005). The coals from the Peñarroya basin are also bituminous and vitrinite-rich. As in the case of the other Carboniferous coals, the ash and sulfur contents vary (Marques, 2002). The Puertollano coals which are vitrinite rich, with variable ash contents and low sulfur percentages are of high volatile bituminous rank (Jiménez et al., 1999 and Alastuey et al., 2001). The sample selected from Teruel is of subbituminous coal rank. This coal is characterized by a $14 \%$ ash content and a high sulfur percentage (3.36\%) (Suárez-Ruiz et al., 1994). The lignites from As Pontes and Meirama are 
vitrinite rich coals with relatively high sulfur contents. The coals from the Saldes coal basin have relatively high sulfur contents (3.13-3.49\%) and are rich in inertinite.

\subsection{Lead content and lead isotope ratios}

The lead content in the coals studied ranges from less than 1 to more than 300 ppm (Table 1). High variations in lead concentration may be observed not only between coals of different rank and origin but also between coals from the same coal seam. The highest concentrations of lead (130 and $300 \mathrm{ppm})$ were found in the samples from the Puertollano coal basin. In a previous work, galena was identified in high proportions in these samples (Jiménez et al, 1999). In general, the lowest concentrations were found in the Pedraforca coals from the Saldes coalfield. The lead isotope ratios ${ }^{206} \mathrm{~Pb} /{ }^{207} \mathrm{~Pb}$ and ${ }^{208} \mathrm{~Pb} /{ }^{206} \mathrm{~Pb}$ for all the coal samples studied are presented in Table 2. Values of ${ }^{206} \mathrm{~Pb} /{ }^{207} \mathrm{~Pb}$ and ${ }^{208} \mathrm{~Pb} /{ }^{206} \mathrm{~Pb}$ range between 1.13 and 1.27 and between 1.94 and 2.11 , respectively.

\section{Discussion}

No relationship between lead content and ash yield for the different coal samples was observed. However, when the samples from an individual coal basin were evaluated, a certain correlation between ash content and lead concentration was found. As an example in the evaluation of lead/ash correlations for the Asturian coals, the findings, presented in Fig 1, indicate the presence of lead species mainly associated with the mineral matter in these coals.

Statistic correlations were also performed between all the parameters of coal characterization and the lead isotope ratios for the whole coal samples. Linear correlation coefficients (r), ranging from 0.62 to 0.81 , were obtained between some lead 
isotope ratios and some petrographic and chemical parameters. The highest values for the correlation coefficient (r), in the whole samples studied, corresponded to the ${ }^{206} \mathrm{~Pb} /{ }^{207} \mathrm{~Pb}$ ratio and inertinite content $(\mathrm{r}=0.795)$ and the ${ }^{208} \mathrm{~Pb} /{ }^{206} \mathrm{~Pb}$ ratio and total sulphur content $(\mathrm{r}=0.821)$ (Fig 2).

The results were compared with the published data for other coals of different origin (Table 3), in which ${ }^{206} \mathrm{~Pb} /{ }^{207} \mathrm{~Pb}$ isotope ratio values were all in the $1.16-1.21$ range, with the exception of Shanghai coal. Most of the Spanish samples studied in this work also have lead isotope ratios in the same range, the exceptions being the coal samples from the Cretaceous Saldes basin and Utrillas-Escucha coalfields (Table 1), which are more radiogenic and present ${ }^{206} \mathrm{~Pb} /{ }^{207} \mathrm{~Pb}$ ratios ranging from 1.22 to 1.27. When the ${ }^{206} \mathrm{~Pb} /{ }^{207} \mathrm{~Pb}$ ratio is plotted versus the ${ }^{208} \mathrm{~Pb} /{ }^{206} \mathrm{~Pb}$ ratio (Fig 3) some general tendencies may be observed and coals can be classified into different groups. The bituminous coals, formed during the Pennsylvanian, all of which have ${ }^{206} \mathrm{~Pb} /{ }^{207} \mathrm{~Pb}$ ratios between 1.16-1.21, have been included in group 1. These coals are in the same region as most of the bituminous coals reported in the literature (Table 3). Group 2 includes the lignite samples from the As Pontes and Meirama coal basins in addition to the Cretaceous and Jurassic coals. The coals in group 2 have a similar ${ }^{206} \mathrm{~Pb} /{ }^{207} \mathrm{~Pb}$ content to group 1 (1.16-1.22), although this is lower for coals from the As Pontes coal basin (1.13). Moreover, the coals included in group 2 have lower ${ }^{208} \mathrm{~Pb} /{ }^{206} \mathrm{~Pb}$ values compared to group 1 ranging from 2.00 to 2.02 . Finally group 3 is made up of samples from the Upper Cretaceous (Garumnian) period. These have higher ${ }^{206} \mathrm{~Pb} /{ }^{207} \mathrm{~Pb}$ ratios than those from the Carboniferous period, ranging from 1.20 to 1.27 . The lowest ${ }^{208} \mathrm{~Pb} /{ }^{206} \mathrm{~Pb}$ ratio values correspond to coal samples included in this group (1.94-2.00), whereas the highest ${ }^{208} \mathrm{~Pb} /{ }^{206} \mathrm{~Pb}$ ratio values were obtained for the coal samples classified in group 1 (2.05-2.11). The coal from the Peñarroya basin is the only exception, as it cannot be 
clearly classified in any of the groups. Although it was formed during the Pennsylvanian period (group 1), the isotopic ratios correspond to the samples included in group 2.

A comparison of the isotopic ratios of the coals studied in this work with the isotope ratios of ores from other Mediterranean countries (http://www.brettscaife.net/lead/data/index.html) (Fig 4) allows some general conclusions to be drawn. Coal samples classified in group 1 have ${ }^{206} \mathrm{~Pb} /{ }^{207} \mathrm{~Pb}$ and ${ }^{208} \mathrm{~Pb} /{ }^{206} \mathrm{~Pb}$ isotope ratio values which are similar to those of galena, pyrite and chalcopyrite. In some coals, as in the case of Puertollano, in which galena was identified in a previous work (Jiménez et al., 1999), the isotopic composition is close to that of the mineral galena. Lignites from the As Pontes basin and the Meirama coalfield exhibit values that are the furthest from the ore isotope values. Although lead has been identified as having aluminositicate affinity in these coals (Huerta, 2001), in low rank coal samples, lead can also be expected to be associated to the organic matter. Samples classified in group 3, from the Saldes basin (Pedraforca coals), have isotope ratios in a line between the different isotope ratios found for malachite (http://www.brettscaife.net/lead/data/index.html). This coal seam is interbedded with carbonates.

The deviations between the isotopic ratios of different coals may be due not only to the various modes of occurrence of lead in different coals, but also to the possible presence of several lead species in a individual coal, incorporated from several sources. By fractionating the coal using the densimetric separation method, it is possible to obtain several fractions of a different mineral matter content and composition. A study of the lead content and lead isotope ratios in these fractions may help towards an understanding of differences in lead composition. If lead were present in the form of a 
single species, the physical densimetric fractionation of the coal samples would not have any influence on the isotope ratios. The ratios would be the same in all the fractions because the physical fractionation of the samples should not theoretically have any influence on the isotope ratios. However, when we analysed the isotope ratios in the densimetric fractions of the bituminous coal, a linear trend was observed within the densimetric series. Higher ${ }^{206} \mathrm{~Pb} /{ }^{207} \mathrm{~Pb}$ ratios (Fig 5) were obtained for the heaviest fractions $\left(>2.60{\mathrm{~g} . \mathrm{cm}^{-3}}^{-3}\right.$ which are enriched in mineral matter (higher ash content). The isotope ratios in the individual fractions are lower than in the raw coals in all cases, which suggest that lead of diverse origin or mode of occurrence is present in the different fractions.

\section{Conclusions}

Lead may be present in coals in different modes of occurrence. The evaluation of lead isotope ratios provides useful information that helps to discriminate between the different lead species.

Although more information is necessary to ascertain the significance of the correlation of lead isotope ratios with coal characterization parameters, the results in this work on isotope ratios and lead concentrations in Spanish coals of different ages (from the Pennsylvanian to the Miocene age), can be regarded as an important contribution to a lead isotope ratio database that could serve as an aid in interpreting sources of pollution.

\section{References}

Agueda, J.A., Bahamonde, J.R., Barba, F.J.,Barba, P., Colmenero, J.R., Fernandez, L.P., Salvador, C.I., Vera, C. 1991. depositional environments in Wetsphalian 
coal.bearing successions of the Cantabrian Mountain, Northwest Spain. In: Bertrand, P. (Ed.,), Coal: Formation, ocurrence and related proper ties. Bulletin de la Socièté Géologique de France 162, 325-33.

Alastuey, A., Jiménez, A., Plana,F., Querol, X., Suárez-Ruiz, I. 2001. Geochemistry, mineralogy, and technological properties of the main Stephanian (Carboniferous) coal seams from the Puertollano Basin, Spain. International Journal of Coal geology $45,247-265$.

Aller, J., Brime, C., 1985. Deformación y metamorfismo en la pate Sur de la Cuenca Carbonífera central (NO de España). Compte rendu du Dixième Congrès International de Stratigraphie et de Géologie du Carbonifère 1983, Madrid, Spain 3, $541-548$.

ASTM Standard D-4371-98, Standard Test Method for Determining the Washability characteristics of a coal

Billstrom, K., Weihed, P., 1996. Age and provenance of host rocks and ores in the paleoproterozoic Skellefte district, northern Sweden. Economic Geology 91, 10541072.

Cabrera, LL., Hagemann, H.H., Pickel, W., Sáez, A., 1995. The coal-bearing, Cenozoic As Pontes Basin (northwestern Spain): geological influence on coal characteristics. International Journal of Coal Geology 27, 201-226.

Chen J., Tan M., Li Y., Zhang Y., Lu W., Tong Y., Zhang G., Li Y., 2005. A lead isotope record of Shanghai atmospheric lead emissions in total suspended particles during the period of phasing out of leaded gasoline. Atmospheric Environment 39, 1245-1253. 
Farmer J.G., Eades L.J., Graham M.C., 1999. The lead content and isotopic composition of British coals and their implications for past and present releases of lead to the UK environment. Environ. Geochem. Health 21, 257-272.

Fernández, L.P. 1995. El Carbonífero. In: Aramburu, C., Bastida, F. (Eds.), Geología de Asturias. Ediciones TREA, Principado de Asturias, Spain, 63-80.

Flament P., Bertho M.L., Deboudt K., Véron A., Puskaric E., 2002. European isotopic signatures for lead in atmospheric aerosols: a source apportionment based upon ${ }^{206} \mathrm{~Pb} /{ }^{207} \mathrm{~Pb}$ ratios. The Science of the Total Environment 296, 35-57.

Fuente-Alonso, P., Sáenz de Santa María Benedet, J.A. 1999. La tectónica y microtectónica de la Cuenca Carbonífera Central de Asturias: vol. Homenaje a J. Truyols. Universidad de Oviedo, Trabajos de Geología 21, 121-140.

Huerta, A. 2001. Caracterización mineralógica y geoquímica de los lignitos de la cuenca Terciaria de As Pontes (Provincia de la Coruña). Acta Geológica Hispanica 36, 183186.

IGME, 1985. Actualización del inventario de recursos nacionales de carbón. Instituto Geológico y Minero de España. Ministerio de Industria y Energía. AIRNC-85, 217 pp.

IGME, 1979. Inventario de recursos de carbón en España. Centro de estudios de la Energía. Comisaría de la energía y recursos minerales. Ministerio de Industria y Energía. 168 pp.

Internacional Standard ISO 589, 2003. Hard coal. Determination of total moisture. Internacional Standard, 2nd edn., 6 pp.

Internacional Standard ISO 562, 1998. Hard coal and coke. Determination of volatile matter content. Internacional Standard, 2nd edn., 5 pp. 
Internacional Standard ISO 1171, 1997. Solid mineral fuels. Determination of ash. Internacional Standard, 2nd edn., 2 pp.

Internacional Standard ISO 7404/2, 1985. Methods for petrographic análisis of bituminous coals and anthracite. Part 2: Preparation of coal samples. Switzerland. 8 pp.

Internacional Standard ISO 7404/3, 1994a. Methods for petrographic análisis of bituminous coals and anthracite. Part 3: Method of determining maceral group composition. Switzerland. 6 pp.

Internacional Standard ISO 7404/5, 1994b. Methods for petrographic análisis of bituminous coals and anthracite. Part 5: Method of determining microscopically the reflectance of vitrinite. Switzerland. $12 \mathrm{pp}$.

Jiménez, A., Martínez-Tarazona, M.R., Suárez-Ruiz, I. 1999. Paleoenvironmental conditions of Puertollano coals (Spain): petrological and geochemical study. International Journal of Coal geology, 41, 189-211.

Kylander M.E., Weiss D.J., Martínez Cortizas A., Spiro B., Garcia-Sanchez R., Coles B.J. 2005. Refining the pre-industrial atmospheric $\mathrm{Pb}$ isotope evolution curve in Europe using an 8000 year old peat core from NW Spain. Earth and Planetary Science Letters 240, 467-485.

Marcoux E., Milesi J.P., 1993. Signature of early proterozoic ore-deposits in Western Africa- comparison with gold deposits in French-Guiana. Economic Geology 88, 1862-1879.

Martinez Cortizas A., Garcia-Rodeja E., Pontevedra Pombal X., Nóvoa Muñoz J.C., Weiss D., Cheburkin A., 2002. Atmospheric Pb deposition in Spain during the last 
4600 years recorded by two ombotrophic peat bogs and implications for the use of peat as archive. The Science of the Total Environment 292, 33-44.

Marques, M.M., 1993. Contribuçao para o conhecimento da petrologia dod carvoes da bacia de Peñarroya-Belmez-Espiel (Cordova-Espanha). PhD Thesis, University of Porto, Portugal.

Marques, M.M. 2002. Coal facies and depositional environments of the Aurora and Cabeza de vaca Units, Peñarroya-belmez-espiel Coalfield (Cordoba, Spain). International Journal of Coal geology, 48, 197-216.

Mukai H., Machida T., Tanaka A., Vera Y.P., Uematsu M., 2001. Lead isotope ratios in the urban air of eastern and central Russia. Atmos. Environ. 35, 2783-2793.

Pardo, G.1979. estratigrafía y sedimentología de las Formaciones detríticas del Cretácico Inferior terminal en el Bajo Aragón turolense. PhD. Thesis. Universidad de Zaragoza, $450 \mathrm{pp}$.

Piedad- Sánchez, N., Suárez-Ruiz, I., Martínez, L., Izart, A., Elie, M., Keravis, D., 2004. organic petrology and geochemistry of the Carboniferous coal seam from the Central Asturian Coal basin (NW Spain). International Journal of Coal Geology 57, $211-242$

Piedad- Sánchez, N., Izart, A., Martínez, L., Suárez-Ruiz, I., Elie, M., Menetrier, C. 2005. Paleothermicity in the Central Asturian Coal basin, North Spain. International Journal of Coal Geology, 58, 205-229.

Querol, X. 1990. Distribución de azufre y material mineral en los carbones de la Formación Escucha. Relaciones con los factores geológicos, sedimentológicos y diagenéticos. PhD. Thesis, Universidad de Barcelona, 523 pp. 
Querol, X., Fernandez, J.L., López, A., hagemann, J.W., Dehmer, J., Juan, R., Ruiz, C., 1991. Distribution of sulfur in coals of the Teruel Mining district, Spain. International Journal of Coal Geology 18, 327-346.

Renberg I., Brännvall M.L., Bindler R., Emteryd O., 2002. Stable lead isotopes and lake sediments - a useful combination for the study of atmospheric lead pollution history. The Science of the Total Environment 292, 45-54.

Ruiz Encinar J., García Alonso J.I., Sanz-Medel A., Main S., Turner P., 2001. A comparison between quadrupole, double focusing and multicollector ICP-MS instruments. Part I: Evaluation of total combined uncertainty for lead isotope ratio measurements. Journal of Analytical Atomic Spectrometry 16, 315-321.

Sáenz de Santa María, J.A., Luque C., Gervilla, M., laveine, J.P., Loboziak, S., Brousmiche, C., Coquel.,R., Martínez-Díaz C., 1985. Aportación al conocimiento estratigráfico y sedimentológico del Carbonífero productivo de la Cuenca central Asturiana. Compte Rendu du Duxieme Congrès International de Stratigraphie et de Géologie du carbonifère 1983, Madrid, Spain. 1, 303-326

Schudak, M. 1987. Charophytenflora und fazielle entwicklung der grenzschichten mariner Jura/Wealden in den nordwestlichen Iberischen ketten (mit vergleichen zu Asturien und Kantabrien). Palaeontographica B 204, 1-180.

Soler-Gijón, R. 1991. Presencia del género Lissodus Brough, 1935 (Chondrichtyes:selachii) en el Carbonífero Superior (Estefaniense B alto / C bajo) de Puertollano, Ciudad Real. Jornadas de Paleontología. Universidad de Oviedo, VII, 55

Suarez Vega, L. 1974. Estratigrafía del Jurásico de Asturias. Cuadernos de Geología Ibérica. 3 (I \& II), 368 pp. 
Suárez-Ruiz, I., Iglesias, M.J., Jiménez, A., Laggoun-Defarge, F., Prado, J.G., 1994b. Influence of resinite on huminite properties. Energy and Fuels 8, 1417-1424.

Sugden C.L., Farmer J.G., Mackenzie A.B. 1993. Isotopic ratios of lead in contemporary environmental material from Scotland, Environ. Geochem. Health, 15 $(2 / 3), 59-65$.

Swaine D.J., 1990. Trace elements in coal. Butterworths\& Co. publishers

Taylor, G.H., Teichmüller, M., Davis, A., Diessel, C.F.K., Littke, R., Robert, P. 1998. Organic Petrology. Gebrüder Borntraeger, Berlin. 704 pp.

UNE 32 300, 1995. Hulla y antracita. Petrografía. Preparación de muestras de carbón para análisis microscópico. AENOR, 13 pp.

Valenzuela, M., García-Ramos, J.C., Suárez de Centi, C. 1986. The Jurassic sedimentation in Asturias (N. Spain). Trabajos de Geología, Universidad de Oviedo, $16,121-132$.

Wagner, R.H., 1999. Peñarroya, a strike-slip controlled basin of early Westphalian age in Southwest Spain. Bull. Czech geol. Surv. 74 (2), 87-108.

Wallis, R.J., 1983. A lacustrine/deltaic/fluvial/swamp succession from the Stephanian B of Puertollano, Spain. In: lemos de Sousa, M.J., Wagner, R.H. (Eds.) Papers on the Carboniferous of the Iberian Peninsula (Sedimentology, Stratigraphy, paleontology and Geocronology). Anals faculdades de Ciencias, Universidade do Porto, 64, 5167.

Walraven N., Van Os B.J.H., Klaver G.T., Baker J.H.,Vriend S.P., 1997. Trace element concentrations and stable lead isotopes in soils as tracers of lead pollution in GraftDe Rijp, The Netherlands J Geochem. Explor., 59, 47-58. 
Weiss D., Shotyk W., Kramers J.D., Gloor M., 1999. Sphagnum mosses as archives of recent and past atmospheric lead deposition in Switzerland. Atmos. Environ., 33, $3751-3763$.

Weiss D., Shotyk W., Boyle E.A., Kramers J.D., Appleby P.G., Cheburkin A.K., 2002. Comparative study of the temporal evolution of atmospheric lead deposition in Scotland and eastern Canada using blanket peat bogs. The Science of the Total Environment 292, 7-18.

http://www.brettscaife.net/lead/data/index.html 
Table 1

Maceral content, vitrinite reflectance and some significant chemical parameters for the coals studied in this work.

\begin{tabular}{|c|c|c|c|c|c|c|c|c|c|c|c|}
\hline Spanish Basin & Age & Sample & $\begin{array}{l}\mathrm{R}_{0} \\
(\%)\end{array}$ & $\begin{array}{l}\text { Vitrinite } \\
\text { (\% vol.) }\end{array}$ & $\begin{array}{l}\text { Liptinite } \\
\text { (\% vol.) }\end{array}$ & $\begin{array}{c}\text { Inertinite } \\
(\% \text { vol })\end{array}$ & $\begin{array}{l}\mathrm{vm} \\
(\%, \mathrm{db})\end{array}$ & $\begin{array}{l}\text { ash } \\
(\%, d b)\end{array}$ & $\begin{array}{l}\text { Total S } \\
(\%, \mathrm{db})\end{array}$ & $\begin{array}{l}\mathrm{C} \\
(\%, \text { daf })\end{array}$ & $\begin{array}{l}{[\mathrm{Pb}]} \\
\mathrm{ppm}\end{array}$ \\
\hline \multirow{9}{*}{$\begin{array}{l}\text { Central } \\
\text { Asturian } \\
\text { Basin }\end{array}$} & \multirow{9}{*}{$\begin{array}{l}\text { Carboniferous } \\
\text { (Pennsylvanian) }\end{array}$} & B1 & 0.77 & 92.4 & 5.1 & 2.5 & 23.7 & 35.8 & 2.29 & 81.3 & 74.5 \\
\hline & & $\mathrm{B} 2$ & 0.78 & 86.8 & 9.0 & 4.2 & 37.4 & 5.05 & 0.68 & 81.3 & 3.99 \\
\hline & & B3 & 0.82 & 70.8 & 9.2 & 20.0 & 33.8 & 4.78 & 0.47 & 85.9 & 2.74 \\
\hline & & B4 & 0.89 & 80.5 & 8.0 & 11.5 & 35.6 & 11.4 & 0.68 & 82.1 & 7.47 \\
\hline & & B5 & 0.89 & 79.1 & 11.5 & 9.4 & 19.9 & 49.1 & 1.08 & 80.4 & 17.5 \\
\hline & & B6 & 0.99 & 85.9 & 4.7 & 9.4 & 33.3 & 6.35 & 1.57 & 85.3 & 6.87 \\
\hline & & B7 & 1.04 & 81.3 & 8.8 & 9.9 & 31.1 & 6.08 & 0.63 & 86.8 & 5.35 \\
\hline & & B8 & 1.82 & 85.0 & 0.0 & 15.0 & 14.3 & 16.4 & 0.64 & 89.2 & 19.7 \\
\hline & & $\mathrm{A} 1$ & 2.54 & 76.0 & 0.0 & 24.0 & 8.06 & 4.09 & 0.48 & 91.9 & nd \\
\hline \multirow{4}{*}{$\begin{array}{l}\text { Peñarroya } \\
\text { Basin }\end{array}$} & \multirow{4}{*}{$\begin{array}{l}\text { Carboniferous } \\
\text { (Pennsylvanian) }\end{array}$} & B9 & 0.68 & 85.9 & 11.6 & 2.5 & 31.7 & 22.3 & 0.38 & 79.7 & 27.2 \\
\hline & & $\mathrm{B} 10$ & 0.90 & 76.5 & 18.8 & 4.7 & 38.6 & 43.4 & 0.34 & 77.9 & 54.4 \\
\hline & & $\mathrm{A} 2$ & 2.47 & 91.0 & 0.0 & 9.0 & 9.71 & 27.9 & 1.14 & 89.7 & 29.8 \\
\hline & & $\mathrm{A} 3$ & 3.20 & 82.3 & 0.0 & 17.7 & 8.62 & 23.4 & 0.66 & 85.8 & 24.6 \\
\hline \multirow{3}{*}{$\begin{array}{l}\text { Puertollano } \\
\text { Basin }\end{array}$} & \multirow{3}{*}{$\begin{array}{l}\text { Carboniferous } \\
\text { (Pennsylvanian) }\end{array}$} & B11 & 0.60 & 65.3 & 10.1 & 24.6 & 28.6 & 28.2 & 1.15 & 82.7 & 302 \\
\hline & & $\mathrm{B} 12$ & 0.66 & 72.5 & 10.6 & 16.9 & 35.5 & 11.5 & 1.22 & 82.6 & 132 \\
\hline & & B13 & 0.68 & 66.4 & 11.1 & 22.5 & 29.3 & 18.8 & 0.81 & 84.4 & 38.4 \\
\hline $\begin{array}{l}\text { Asturian } \\
\text { Jurassic Basin }\end{array}$ & $\begin{array}{l}\text { Jurassic } \\
\text { (Kimmeridgian) }\end{array}$ & B14 & 0.72 & 100.0 & 0.0 & 0.0 & 54.9 & 1.10 & 1.00 & 84.8 & 2.70 \\
\hline \multirow{3}{*}{$\begin{array}{l}\text { Saldes Basin } \\
\text { (Pedraforca ) }\end{array}$} & \multirow{3}{*}{$\begin{array}{l}\text { Upper } \\
\text { Cretaceous } \\
\text { (Garumnian) }\end{array}$} & B15 & 0.64 & 52.1 & 1.4 & 46.5 & 31.9 & 46.5 & 3.35 & 74.1 & 5.46 \\
\hline & & B16 & 0.63 & 64.1 & 4.1 & 31.8 & 34.8 & 49.3 & 3.49 & 71.4 & 2.97 \\
\hline & & B17 & - & - & - & - & 38.4 & 44.1 & 3.13 & 70.3 & 1.4 \\
\hline $\begin{array}{l}\text { Utrillas- } \\
\text { Escucha } \\
\text { Coalfield }\end{array}$ & $\begin{array}{l}\text { Cretaceous } \\
\text { (Albian) }\end{array}$ & $\mathrm{Sb} 1$ & 0.38 & 80.5 & 1.8 & 17.7 & 38.7 & 13.9 & 3.36 & 79.9 & 6.31 \\
\hline \multirow{2}{*}{$\begin{array}{l}\text { As Pontes } \\
\text { Basin }\end{array}$} & \multirow{2}{*}{$\begin{array}{l}\text { Cenozoic } \\
\text { (Oligocene- } \\
\text { Miocene) }\end{array}$} & L1 & 0.23 & 83.6 & 0.0 & 16.4 & 49.5 & 22.6 & 3.32 & 89.4 & 28 \\
\hline & & L2 & 0.24 & 87.6 & 5.3 & 7.1 & 64.5 & 13.9 & 1.84 & 84.8 & 14 \\
\hline $\begin{array}{l}\text { Meirama } \\
\text { Coalfield }\end{array}$ & $\begin{array}{l}\text { Cenozoic } \\
\text { (Miocene) }\end{array}$ & L3 & 0.23 & 83.6 & 0.0 & 16.4 & 51.3 & 15.6 & 2.57 & 84.5 & $<1$ \\
\hline
\end{tabular}

$\mathrm{R}_{0}$ : Vitrinite reflectance; vm: Volatile matter; db: dry basis; daf: dry ash free basis 
Table 2.

Lead isotope ratios of the coals studied

\begin{tabular}{|c|c|c|c|}
\hline Spanish Basin & Ref. & ${ }^{206} \mathrm{~Pb} /{ }^{207} \mathrm{~Pb}$ & ${ }^{208} \mathrm{~Pb} /{ }^{206} \mathrm{~Pb}$ \\
\hline \multirow{9}{*}{$\begin{array}{l}\text { Central } \\
\text { Asturian } \\
\text { Basin }\end{array}$} & B1 & $1.181 \pm 0.001$ & $2.088 \pm 0.001$ \\
\hline & B2 & $1.202 \pm 0.001$ & $2.066 \pm 0.001$ \\
\hline & B3 & $1.189 \pm 0.001$ & $2.089 \pm 0.001$ \\
\hline & B4 & $1.185 \pm 0.001$ & $2.073 \pm 0.001$ \\
\hline & B5 & $1.183 \pm 0.001$ & $2.103 \pm 0.001$ \\
\hline & B6 & $1.186 \pm 0.001$ & $2.081 \pm 0.001$ \\
\hline & B7 & $1.200 \pm 0.001$ & $2.091 \pm 0.001$ \\
\hline & B8 & $1.201 \pm 0.001$ & $2.073 \pm 0.001$ \\
\hline & A1 & $1.155 \pm 0.001$ & $2.110 \pm 0.001$ \\
\hline \multirow{4}{*}{$\begin{array}{l}\text { Peñarroya } \\
\text { Basin }\end{array}$} & B9 & $1.165 \pm 0.001$ & $2.108 \pm 0.001$ \\
\hline & B10 & $1.185 \pm 0.001$ & $2.069 \pm 0.001$ \\
\hline & $\mathrm{A} 2$ & $1.184 \pm 0.001$ & $2.093 \pm 0.001$ \\
\hline & A3 & $1.189 \pm 0.001$ & $2.033 \pm 0.001$ \\
\hline \multirow{3}{*}{$\begin{array}{l}\text { Puertollano } \\
\text { Basin }\end{array}$} & B11 & $1.178 \pm 0.001$ & $2.099 \pm 0.001$ \\
\hline & B12 & $1.180 \pm 0.001$ & $2.097 \pm 0.001$ \\
\hline & B13 & $1.179 \pm 0.001$ & $2.097 \pm 0.001$ \\
\hline $\begin{array}{l}\text { Asturian } \\
\text { Jurassic Basin }\end{array}$ & B14 & $1.215 \pm 0.001$ & $2.025 \pm 0.001$ \\
\hline \multirow{3}{*}{$\begin{array}{l}\text { Saldes Basin } \\
\text { (Pedraforca ) }\end{array}$} & $\mathrm{B} 15$ & $1.268 \pm 0.001$ & $1.944 \pm 0.001$ \\
\hline & B16 & $1.240 \pm 0.001$ & $1.999 \pm 0.001$ \\
\hline & B17 & $1.255 \pm 0.001$ & $1.958 \pm 0.001$ \\
\hline $\begin{array}{l}\text { Utrillas- } \\
\text { Escucha } \\
\text { Coalfield }\end{array}$ & $\mathrm{Sb} 1$ & $1.222 \pm 0.001$ & $2.037 \pm 0.001$ \\
\hline \multirow{2}{*}{$\begin{array}{l}\text { As Pontes } \\
\text { Basin }\end{array}$} & L1 & $1.130 \pm 0.002$ & $2.017 \pm 0.002$ \\
\hline & L2 & $1.130 \pm 0.002$ & $2.017 \pm 0.002$ \\
\hline $\begin{array}{l}\text { Meirama } \\
\text { Coalfield } \\
\end{array}$ & L3 & $1.183 \pm 0.002$ & $2.019 \pm 0.001$ \\
\hline
\end{tabular}


Table 3.

${ }^{206} \mathrm{~Pb} /{ }^{207} \mathrm{~Pb}$ in coals: Data from the literature.

\begin{tabular}{lccl}
\hline Origin coal country & n* & $206 / 207$ & Source \\
\hline North China & n.a. & $1.19-1.16$ & Chen at al., 2005 \\
Shanghai & n.a. & $1.14-1.21$ & Chen at al., 2005 \\
Scotland & n.a & $1.16-1.19$ & Sugden et al., 1993 \\
Russia & n.a. & $1.20-1.21$ & Mukai et al., 2001 \\
Great Britain & n.a. & $1.17-1.19$ & Sugden et al., 1993 \\
Ireland & 65 & 1.18 & Farmer et al., 1999 \\
Poland & 65 & 1.18 & Farmer et al., 1999 \\
Switzerland & n.a. & $1.17-1.19$ & Weiss et al., 1999 \\
Netherlands + Belgium & 10 & 1.17 & Walraven at al., 1997 \\
\hline $\mathrm{n} *$ Number of coal samples analysed; n.a. not available &
\end{tabular}




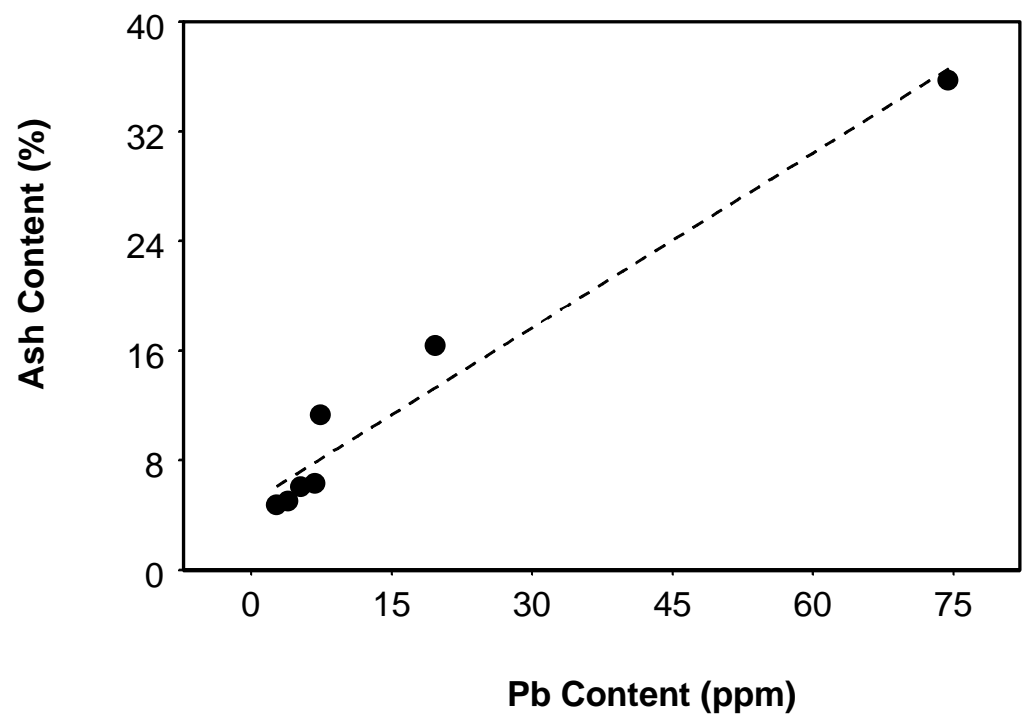

Fig. 1. Relationship between $\mathrm{Pb}$ and ash content for Asturian coals. $(\mathrm{r}=0.721)$

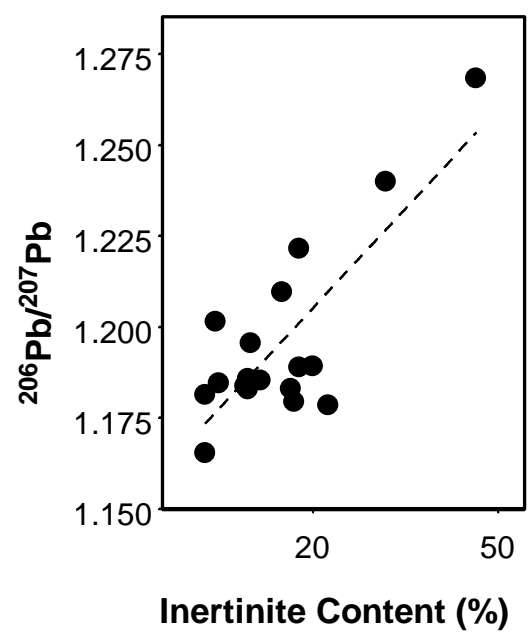

(a)

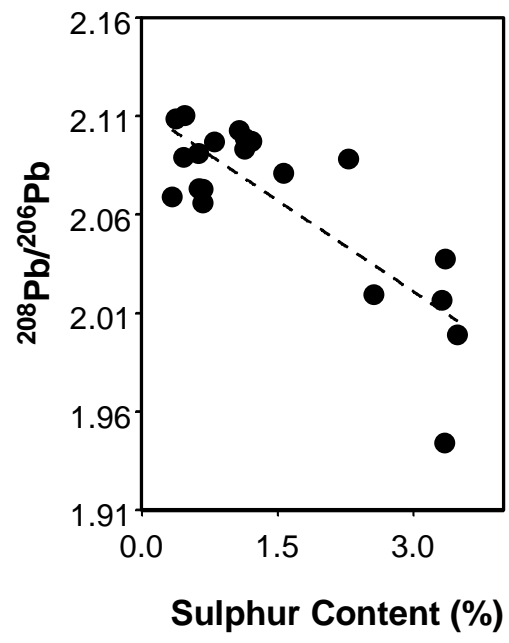

(b)

Fig. 2. Relationships between (a) inertinite content and ${ }^{206} \mathrm{~Pb} /{ }^{207} \mathrm{~Pb}$ lead isotope ratio ( $\mathrm{n}$ $=18 ; \mathrm{r}=0.795)$ and $(\mathrm{b})$ sulphur content and ${ }^{208} \mathrm{~Pb} /{ }^{206} \mathrm{~Pb} \mathrm{~Pb}$ isotope ratio $(\mathrm{n}=21 ; \mathrm{r}=$ 0.821). 


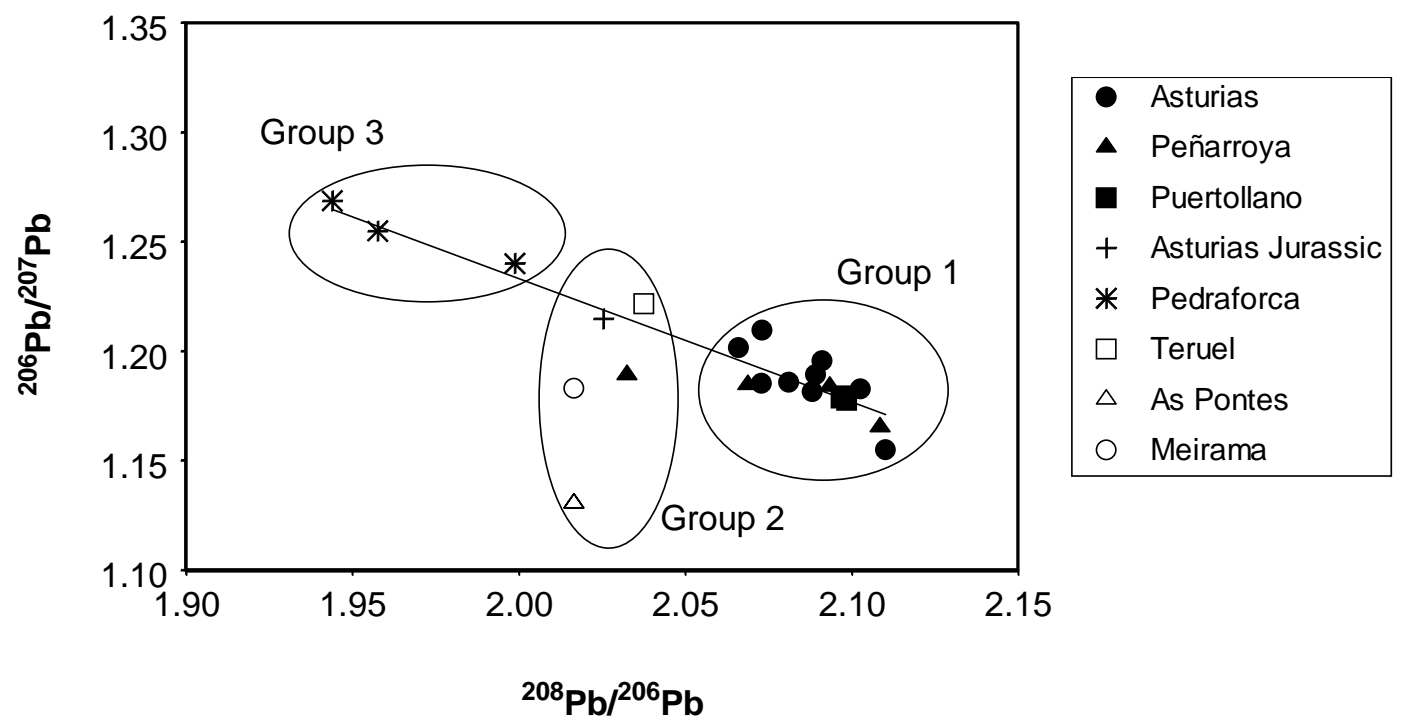

Fig. 3. Isotope ratios $\left({ }^{206} \mathrm{~Pb} /{ }^{207} \mathrm{~Pb}\right.$ vs $\left.{ }^{208} \mathrm{~Pb} /{ }^{206} \mathrm{~Pb}\right)$ obtained for Spanish coals of different origin.

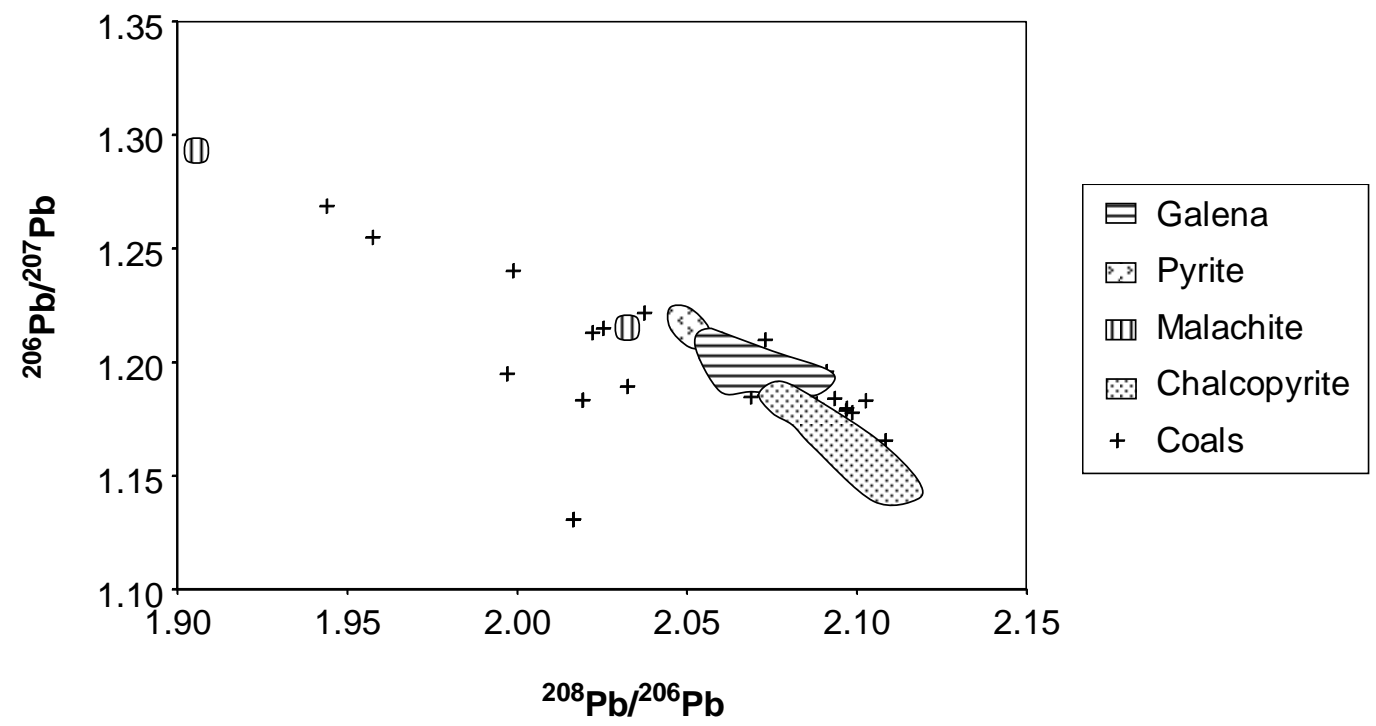

Fig. 4. Isotope ratios $\left({ }^{206} \mathrm{~Pb} /{ }^{207} \mathrm{~Pb}\right.$ vs $\left.{ }^{208} /{ }^{206} \mathrm{~Pb}\right)$ for minerals from different Mediterranean countries in addition to the coal samples evaluated. 


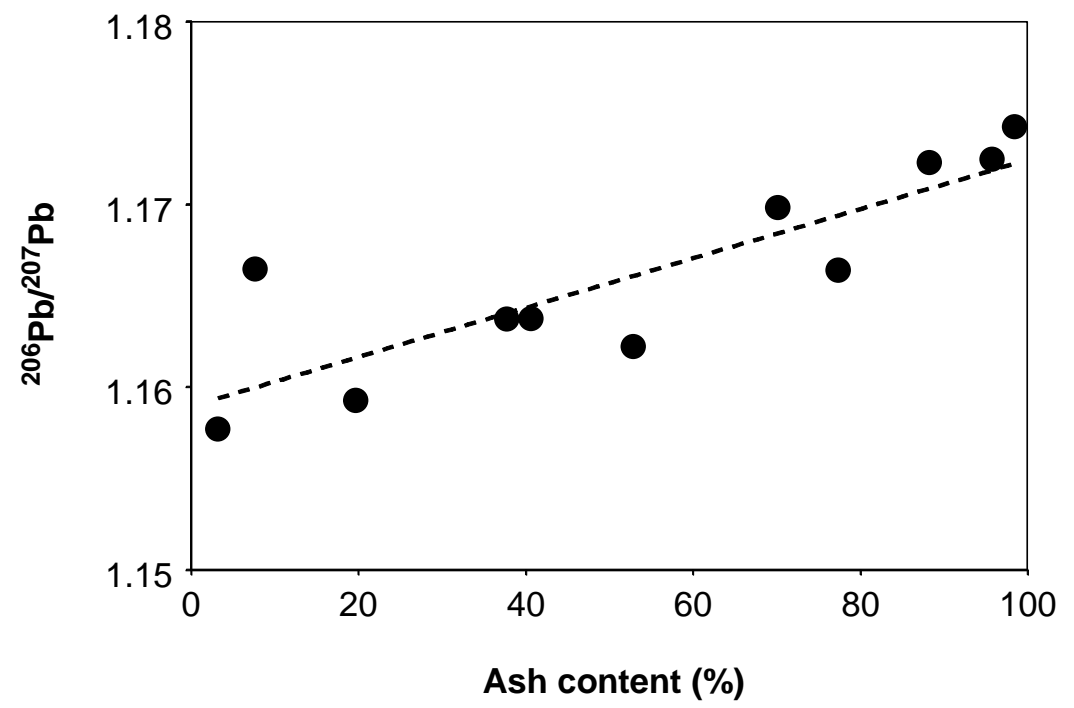

Fig. 5. ${ }^{206} \mathrm{~Pb} /{ }^{207} \mathrm{~Pb}$ lead isotope ratio vs ash content for the different densimetric fractions of a bituminous coal from the Central Asturian basin 